\title{
Keterbatasan Program PHBS dalam Peningkatan Pengelolaan Sampah di RW 5 Kelurahan Ciketing Udik, Kota Bekasi, Jawa Barat
}

\section{Limitation of PHBS Program for Waste Management Improvement in RW 5 Ciketing Udik Subdistrict, Bekasi City, West Java}

\author{
Risca Ardita Novianti ${ }^{1, *)}$, Pudji Muljono ${ }^{2}$, Ekawati Sri Wahyuni ${ }^{2}$
}

${ }^{1}$ Program Studi Magister Pengembangan Masyarakat, Sekolah Pascasarjana IPB University, Bogor 16680, Indonesia

${ }^{2}$ Sains Komunikasi dan Pengembangan Masyarakat, IPB University, Bogor 16680, Indonesia

${ }^{*}$ E-mail korespondensi: riscaardita.n@gmail.com

Diterima: 25 April 2021 | Disetujui: 22 September 2021 | Publikasi Online: 29 September 2021

\begin{abstract}
Bekasi Municipality as one of DKI Jakarta's buffer city, has unique challenges in implementing clean and healthy behavior (PHBS). The existence of Bantargebang landfill is one of challanges in optimizing PHBS. The vast amount of waste in Bantargebang landfill, including valuable waste, attracts outsiders to engage in waste picking and trading opportunity. This leads to the development of slum areas around the landfill, one of which is in RW 5 Ciketing Udik Subdistrict. This study aims to describe the level of understanding of PHBS and solid waste, waste management and the role of stakeholders in encouraging the improvement of PHBS in waste management. The research design is a qualitative approach with support of quantitative data. Survey showed the community have good understanding about PHBS and adequate understanding about waste management in particular, but respondents also admit they don't do much to manage their waste. Open burning become as the community preferred way to manage waste. Lack of access to information, enforcement of regulations, and the willingness and ability of community leaders add challenges for developing a good waste management. Furthermore, the implementation of PHBS and the oversight function has not yet reach the overall PHBS indicators, especially waste management.
\end{abstract}

Keywords: Participation, PHBS, waste management

\section{ABSTRAK}

Kota Bekasi sebagai salah satu kota penyangga DKI Jakarta memiliki tantangan tersendiri dalam menerapkan Perilaku Hidup Bersih dan Sehat (PHBS). Keberadaan TPST Bantargebang menjadi salah satu tantangan dalam mengoptimalkan PHBS. Banyaknya sampah yang masuk ke TPST Bantargebang, termasuk sampah yang berharga, menarik orang luar untuk terlibat dalam pengambilan sampah dan peluang jual beli. Hal ini menyebabkan berkembangnya kawasan kumuh di sekitar TPST Bantargebang, salah satunya di RW 5 Kecamatan Ciketing Udik. Penelitian ini bertujuan untuk menggambarkan tingkat pengetahuan PHBS dan persampahan komunitas RW 5, kondisi pengelolaan sampah serta peran pemangku kepentingan dalam mendorong adanya peningkatan PHBS dalam pengelolaan sampah. Desain penelitian yaitu dengan pendekatan kualitatif dengan dukungan data kuantitatif. Dari hasil survei menunjukkan bahwa masyarakat memiliki pengetahuan yang baik tentang PHBS dan cukup tentang persampahan pada khususnya, tetapi responden juga mengakui bahwa mereka tidak berbuat banyak untuk mengelola sampahnya. Mayoritas warga melakukan pembakaran terbuka sebagai cara yang dipilih dalam mengelola sampah. Minimnya akses informasi, penegakkan aturan dan juga kemauan serta kemampuan pemimpin komunitas turut menambah tantangan dalam penyelenggaraan pengelolaan sampah yang baik. Lebih jauh, penerapan PHBS dan fungsi edukasi serta pengawasan pemerintah belum menyentuh keseluruhan indikator PHBS khususnya pengelolaan sampah.

Kata kunci: Partisipasi, PHBS, pengelolaan sampah 


\section{PENDAHULUAN}

Pembangunan kesehatan adalah upaya penyelenggaraan kesehatan yang bertujuan untuk menciptakan kemampuan hidup yang sehat bagi setiap penduduk, demi terwujudnya kesehatan masyarakat yang lebih optimal. Kesehatan menjadi bagian yang tidak terpisahkan dari pembangunan nasional di mana kesehatan merupakan modal dasar dari kebutuhan masyarakat untuk menunjang capaian dari kualitas hidupnya. Tertuang pada Peraturan Presiden No. 18 Tahun 2020 Tentang RPJMN 2020-2024 (2020) bahwa peningkatan PHBS perlu dilakukan pada tatanan lingkungan keluarga, satuan pendidikan, satuan kerja, dan juga komunitas. Hal ini juga termuat menjadi salah satu program prioritas nasional dalam ranah revolusi mental dan kebudayaan.

Dalam mewujudkan hal tersebut, Pemerintah Kota Bekasi dalam hal ini turut menuangkannya di dalam Rencana Pembangunan Jangka Menengah Daerah tahun 2018-2023 dalam misi 4 yang berupa meningkatkan dan mengembangkan kualitas kehidupan masyarakat yang berpengetahuan, sehat, berakhlak mulia, kreatif dan inovatif (BAPPEDA Kota Bekasi, 2016). Hal tersebut masuk di dalam program pemberdayaan masyarakat di bidang kesehatan dengan indikator cakupan rumah dengan PHBS dengan target 65\% pada tahun 2025. Akan tetapi, dalam mewujudkan hal tersebut, Kota Bekasi bukan tanpa tantangan. Kota Bekasi sebagai penyangga ibukota DKI Jakarta tentunya memiliki tantangan tersendiri di mana DKI Jakarta dalam hal ini merupakan salah satu kota yang memproduksi sampah yang tidak sedikit dibanding dengan kota lain.

Berdasarkan data yang tertera pada (UPST Dinas Lingkungan Hidup DKI Jakarta, n.d.) pada tahun 2019 ratarata TPST Bantargebang menerima sampah sebanyak 7702,07 ton per harinya. Lebih lanjut, kenaikan angka timbulan sampah yang masuk ke TPST Bantargebang sejak tahun 2015 meningkat dengan rata-rata 4\% setiap tahunnya. Berbagai dampak dari terus menerusnya sampah yang masuk ke TPA kerap timbul, mulai dari sisi ekologis maupun lingkungan yang juga berdampak bagi masyarakat sekitar. Menurut Laporan Tahunan Kelurahan Ciketing Udik (2018) menyatakan bahwa keberadaan dari TPST Bantargebang yang berada pada Kelurahan Ciketing Udik meski telah membawa dampak baik berupa tambahan ekonomi bagi masyarakat sekitar dalam melakukan usaha daur ulang namun juga menimbulkan dampak buruk yakni banyaknya gubukgubuk liar yang dihuni oleh para pemulung yang sulit untuk ditertibkan sehingga wilayah Kelurahan Ciketing Udik terkesan kumuh sampai dengan dampak ekologis yang terjadi di sekitar seperti bau yang tidak sedap, lalat dan juga dampak dari air lindi terhadap lingkungan sekitar.

Sejalan dengan dampak yang terjadi akibat keberadaan TPST Bantargebang tersebut menurut Juliansah (2010) telah terjadi eksternalitas negatif lingkungan bersih yang berkurang meliputi udara, lingkungan/ tata ruang, kualitas air dan tanah akibat sampah yang datang dan juga dampak sosial yang terjadi akibat hal tersebut di antaranya berkurangnya bermain anak akibat berkurangnya lahan serta citra lingkungan yang bau dan kurang baik dan terbilang kumuh. Selain itu, penurunan nilai tanah dan bangunan juga mempertambah dampak yang dihasilkan (Maryati, 2019).

Permukiman kumuh dan kondisi pengelolaan sampah yang belum terselenggara dengan baik turut menjadi masalah sosial yang berkaitan dialami oleh komunitas Kelurahan Ciketing Udik. Permukiman kumuh adalah permukiman yang cenderung tidak teratur dari sisi bangunan, tingkat kepadatan bangunan yang tinggi, dan kualitas bangunan serta sarana dan prasarana yang tidak memenuhi syarat tinggal sehingga dikaitkan tidak layak huni (UU No. 1 Tahun 2011). Berdasarkan penelitian Wijayanti (2019) pada tahun 2018 menyatakan bahwa Kelurahan Ciketing udik menjadi Kelurahan nomor dua dengan wilayah yang memiliki luas permukiman kumuh yakni 25,39 ha dan nomor satu untuk KK terbanyak yang tinggal di area permukiman kumuh Kelurahan Ciketing Udik yakni sebanyak $1217 \mathrm{KK}$ atau sebanyak 22,16 persen. Permukiman Kelurahan Ciketing Udik tampak semakin tampak dikarenakan banyaknya sampah yang dibuang sembarang jalan ataupun dibakar.

Tantangan akan permukiman kumuh dan penerapan PHBS juga ditunjukkan pada data Dinas Kesehatan Kota Bekasi tahun 2020 yang tertera dalam https://danta.bekasikota.go.id/ bahwasanya pada tahun 2019 Puskemas Kelurahan Ciketing Udik hanya dapat melakukan pemantauan rumah sebesar 4,2\% dari total KK yang ada. Data ini jauh lebih sedikit dari jumlah KK yang terpantau di Kelurahan Sumur Batu sebagai kelurahan yang juga memiliki permukiman kumuh dengan pemantauan PHBS sebesar 25,6\% dari KK yang ada. Dari data tersebut, dapat disimpulkan bahwa Puskemas Kelurahan Ciketing Udik selaku perwakilan dari instansi pemerintah belum dapat melakukan pengawasan akan PHBS yang lebih merata di daerahnya.

Adapun hal tersebut senada berdasarkan penelitian Cahyadi (2011) bahwa bentuk pengelolaan sampah yang terdapat di pemukiman kumuh dapat dikategorikan menjadi dua, yaitu membuat sendiri tempat penampungan sampah (TPS) dan membuang langsung ke sungai atau tanah kosong. Ditambahkan menurutnya bahwa 
penduduk yang tinggal di pemukiman kumuh tidak masuk ke dalam sistem pengelolaan semacam itu, baik dalam pengertian pengumpulan secara langsung maupun tidak langsung yang kemudian sampah menjadi masalah bagi mereka, yang mesti di atasi dengan kemampuan sendiri. Di samping itu berdasarkan hasil penelitian Martinawati et al., (2016) menyatakan bahwa semakin tinggi tingkat partisipasi yang dimiliki masyarakat maka akan semakin besar peranan masyarakat dalam menentukan bentuk lingkungan yang seperti apa yang diharapkannya karena masyarakat sudah lebih dahulu peduli akan lingkungan sekitarnya sehingga pengelolaan sampah menjadi lebih efektif.

Tidak dipungkiri untuk menuju meningkatnya partisipasi masyarakat, komunitas dapat menemukan hambatan dan tantangannya. Minimnya pengetahuan dan gerakan untuk kualitas hidup yang baik menjadi tantangan tersendiri akan perubahan perilaku yang mendorong ke arah yang lebih baik. Pada hakikatnya pengetahuan turut dapat diakses apabila penyuluhan pembangunan juga masuk ke dalam akses-akses permukiman kumuh secara berkelanjutan dalam hal ini terkait dengan pengelolaan sampah. Sebagaimana menurut Muljono (2007) penyuluhan pembangunan merupakan suatu bentuk pengetahuan tentang bagaimana pola perilaku manusia dapat terbentuk, berubah atau diubah sehingga bisa melepaskan kebiasaan lama yang telah terbentuk dan menggantinya dengan perilaku baru yang lebih berdampak guna meningkatkan kualitas hidup yang lebih baik.

Berdasarkan pemaparan di atas guna mengurai tantangan dan batasan akan program PHBS dalam pengelolaan sampah pada RW Kelurahan Ciketing Udik, maka lebih dalam tujuan ini bertujuan untuk: 1) mengidentifikasi tingkat pengetahuan komunitas RW 5 akan PHBS dan persampahan, 2) mengidentifikasi kondisi pengelolaan sampah berdasar lima aspek pengelolaan sampah dan peran pemangku kepentingan dalam PHBS khususnya pengelolaan sampah di Kelurahan Ciketing Udik, 3) mengidentifikasi peran pemangku kepentingan PHBS.

\section{METODE PENELITIAN}

Pendekatan yang dilakukan dalam penelitian ini adalah pendekatan kualitatif dengan dukungan data kuantitatif. Pendekatan kualitatif dipilih dalam rangka lebih menekankan pada makna-makna serta proses yang terjadi di lapangan yang tidak digambarkan secara kuantitatif. Penelitian ini dilaksanakan di RW 5 Kelurahan Ciketing Udik Kecamatan Bantargebang Kota Bekasi. Lokasi penelitian dipilih secara sengaja oleh peneliti dengan pertimbangan lokasi penelitian sesuai dengan topik yang dikaji, yaitu kelurahan tersebut merupakan permukiman kumuh yang berdekatan dengan TPST Bantargebang. Penelitian ini dilaksanakan pada bulan November 2019 sampai dengan Desember 2020.

Subyek penelitian ini terdiri dari informan dan responden. Data yang didapatkan dari informan didapatkan dengan wawancara mendalam dan FGD serta responden dilakukan dengan survei. Survei diperlukan dalam rangka mendapatkan data perihal tingkat pengetahuan PHBS dan persampahan serta tingkat partisipasi komunitas RW 5. Survei dilakukan kepada 30 responden komunitas RW 5 dengan penentuan sampel berupa Accidental Sampling. Responden pada penelitian ini dipilih secara kebetulan bersedia untuk dilakukan survei pada waktu pengambilan data di wilayah RW 5. Pengambilan data secara aksidental ini juga dipengaruhi oleh kondisi pandemi di mana terdapat batasan ruang gerak interaksi untuk tetap melakukan physical distancing dan tidak semua warga dapat menerima serta berinteraksi dengan orang di luar rumahnya.

Dalam penggalian mengenai kondisi pengelolaan sampah RW 5 secara rinci informasi didapatkan dari informan penelitian melalui wawancara mendalam dan FGD yang terdiri dari kader RW 5, pengurus PKK, pengurus RW dan RT, tokoh masyarakat, Kelurahan Ciketing Udik, dan Dinas Lingkungan Hidup Kota Bekasi. Secara khusus FGD dilakukan untuk mendapatkan kesepakatan terkait penyamaan persepsi dan informasi yang didapatkan sebelumnya mengenai kondisi pengelolaan sampah, akar permasalahan sampah RW 5 dan peran pemangku kepentingan di RW 5. Proses FGD dihadiri oleh pemangku kepentingan lokal RW 5 dan peneliti sebagai fasilitator acara. Berkaitan dengan survei tingkat pengetahuan responden akan PHBS dan persampahan, penelitian ini menentukan skor dari hasil kuesioner dengan teknik skoring tanpa koreksi pada setiap soal pertanyaan pilihan ganda. Jumlah jawaban benar masing-masing responden diklasifikasikan ke dalam 5 kategori tingkat pengetahuan.

Analisis yang dipakai dalam data kualitatif adalah analisis deskriptif. Data yang didapatkan melalui tahapan reduksi dengan rangkuman dari hasil wawancara dan FGD, kemudian disajikan untuk dapat memudahkan penarikan kesimpulan lalu tahapan akhir berupa penarikan kesimpulan. Adapun terkait analisis data dukungan kuantitatif, penelitian ini menggunakan analisis tabulasi frekuensi. 


\section{HASIL DAN PEMBAHASAN}

\section{Gambaran Umum Kelurahan Ciketing Udik}

Kelurahan Ciketing Udik berada di Kecamatan Bantargebang, Kota Bekasi, Provinsi Jawa Barat. Kelurahan Ciketing Udik merupakan salah satu dari empat Kelurahan yang ada di Kecamatan Bantargebang Kota Bekasi dengan luas wilayah sekitar 343.340 Ha yang dibagi atas 9 RW dan 64 RT. Adapun wilayah RW 4, RW 5 dan RW 6 berbatasan langsung dengan area TPST Bantargebang dan menjadikan daerah ini menjadi wilayah yang lekat dengan lokasi pemukiman pemulung terutama pada RW 5.

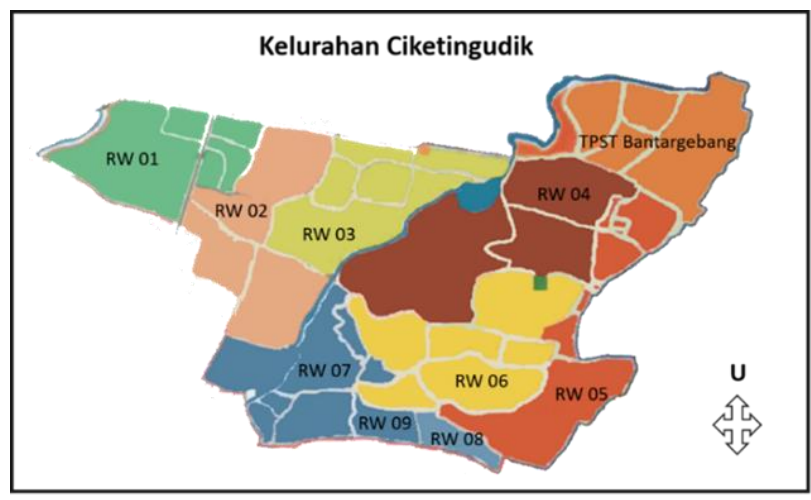

Gambar 1. Peta Kelurahan Ciketing Udik Berdasarkan RW

Sebagai lokasi fokus komunitas pemulung di wilayah Kelurahan Ciketing Udik yakni RW 5, wilayah ini setidaknya memiliki 40 pengepul sampah yang terbagi ke dalam 3 RT yakni di RT 1 dengan jumlah 19 pengepul, RT 2 dengan jumlah 15 pengepul dan RT 3 dengan jumlah 6 pengepul. Adapun pengepul tersebut rata-rata memiliki 5-15 orang pekerja pemulung di setiap masing-masingnya dan juga menjadi wadah perekonomian bagi pemulung di Kelurahan Ciketing Udik dan umumnya sekitar wilayah TPST Bantargebang untuk mencari nafkah sehari-hari dengan hubungan status pekerja maupun mitra dalam bisnis jual-beli sampah. Lebih lanjut, berdasarkan Maulana et al., (2014) manfaat berupa tambahan ekonomi cenderung dirasakan bagi warga pendatang yang berasal dari Madura, sedangkan penduduk asli cenderung memanfaatkannya secara tidak langsung seperti melakukan pekerjaan sebagai mandor, penyewa lahan lapak, sopir pengangkut sampah, dan warung-warung dalam menyediakan kebutuhan pemulung.

Permasalahan yang kemudian timbul dan dirasakan khususnya RW 5 dipetakan sebagai berikut; (1) kualitas lingkungan hidup yang kurang baik seperti air, tanah, dan udara, (2) permasalahan data penduduk yang tidak dapat terekam dengan baik terutama pendatang yakni pemulung, (3) kondisi lingkungan yang kumuh. Di satu sisi, meski RW 5 khususnya mengalami bentuk dampak negatif akan keberadaan TPST Bantargebang yang dirasakan juga bersama dengan 4 kelurahan sekitar. Masyarakat yang berdomisili di wilayah tersebut turut mendapatkan bantuan dan bentuk ganti rugi berupa dana langsung yang turun kepada warga lokal yang memiliki KTP setempat sebesar Rp 900.000,- per 3 bulan dan juga bantuan pemberdayaan yang diberikan melalui LPM (Lembaga Pemberdayaan Masyarakat), serta bantuan infrastruktur lainnya.

\section{Pengetahuan PHBS dan Persampahan}

Untuk menggambarkan pengetahuan, peneliti membagi berdasarkan 5 klasifikasi yakni; (1) sangat baik, (2) baik, (3) cukup baik, (4) kurang baik, dan (5) buruk. Adapun berdasarkan hasil survei yang dilaksanakan pada komunitas RW 5 mengenai pengetahuan terkait PHBS dan persampahan menyimpulkan bahwa sebagian besar komunitas berada pada kategori yang baik terkait pengetahuan tentang apa itu PHBS yakni sebanyak 50 persen dari responden. Menurut Notoatmodjo (2014) pengetahuan merupakan dasar sebuah tindakan dapat dilakukan yang diawali dengan sebuah ide dan kemampuan mengetahui. Selanjutnya tingkat pengetahuan juga dapat menentukan perilaku kesehatan yang dimiliki setiap individu. Selain itu, pengetahuan komunitas akan persampahan pada hasil survei ini juga turut menyimpulkan bahwa pengetahuan serta pengetahuan komunitas akan persampahan berada pada kategori cukup baik yakni sebanyak 60 persen. Lebih lanjut bentuk pengetahuan responden akan PHBS dan persampahan diulas sebagai berikut. 


\section{Pengetahuan PHBS}

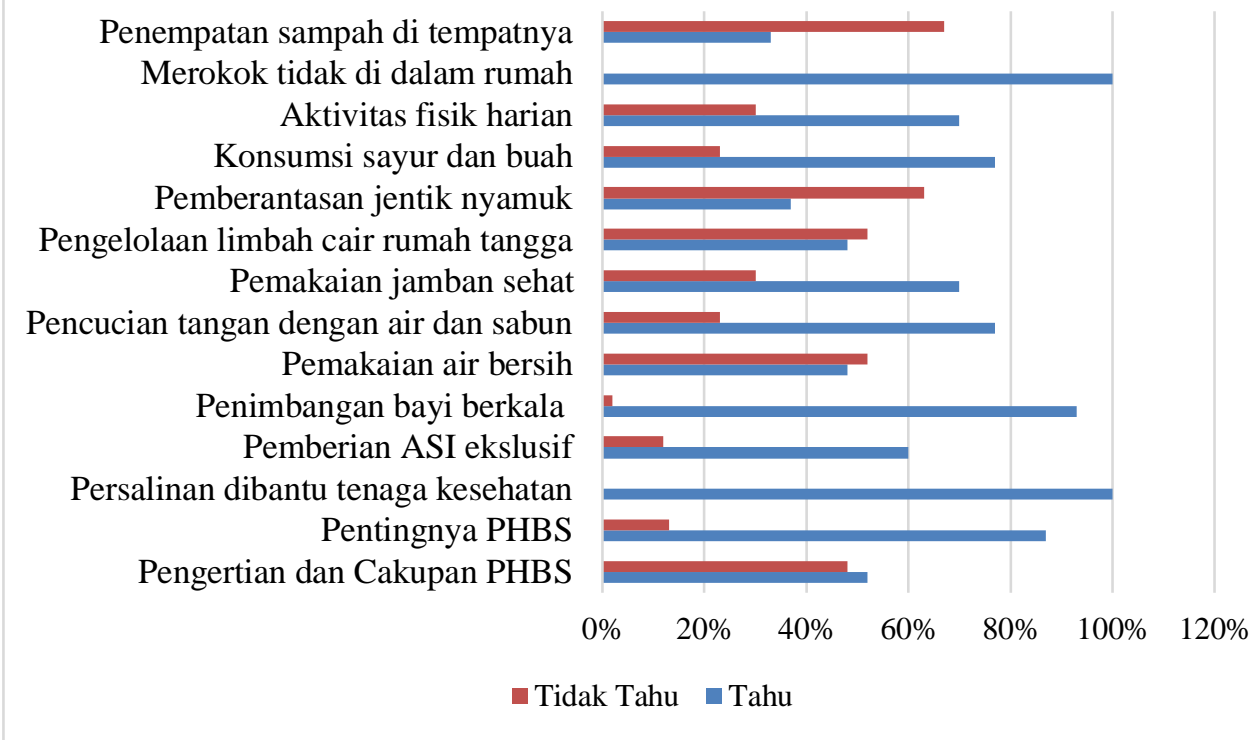

Gambar 2. Pengetahuan PHBS

Dari Gambar 2 di atas responden berada pada kategori cukup untuk memahami arti dari PHBS itu sendiri, seperti kepanjangan dan juga cakupan dari PHBS. Responden juga mengetahui dengan betul pentingnya PHBS dalam kehidupan sehari-hari yang ditandai dengan pengetahuan pada kategori baik. Apabila ditinjau dari indikator PHBS, pengetahuan komunitas akan PHBS mengenai perilaku merokok, pertolongan persalinan oleh tenaga kesehatan, penimbangan bayi secara berkala sudah berada pada kategori sangat baik yakni di atas 80 persen yang memahami akan perilaku hal tersebut. Adapun kategori baik dilihat pada indikator pencucian tangan dengan air dan sabun, penggunaan jamban sehat, aktivitas fisik harian, dan mengonsumsi sayur dan buah. Selanjutnya, pemberian ASI eksklusif, penggunaan air bersih dan pengelolaan limbah cair rumah tangga berada pada kategori cukup.

Hal menarik berkaitan dengan mencuci tangan dengan air bersih dan sabun yakni meski berada pada kategori baik akan tetapi responden tidak memahami dengan baik karakteristik dari air bersih seperti apa. Sementara itu dalam kategori penggunaan air bersih, rata-rata responden menjawab sumber air bersih yang baik adalah air yang bersumber melalui sumur tanah dan atau sumur artesis meski pada pertanyaan terdapat pilihan sumber air dari PAM. Hal ini dapat terjadi dikarenakan wilayah Kelurahan Ciketing khususnya RW 5 belum ada layanan PAM yang tersedia, sehingga bisa menjadi salah satu alasan kenapa responden tidak mengetahui hal ini. Adapun alasan responden menggunakan sumber air artesis dikarenakan air tanah di wilayah tersebut cenderung kering dan bau, sehingga warga mendapatkan fasilitas air artesis. Hanya saja berdasar penuturan responden, air artesis tersebut terkadang pemakaiannya cenderung tidak leluasa karena telah diatur debit airnya untuk masing-masing rumah.

Di sisi lain, pengetahuan mengenai perilaku pembuangan sampah dan pemberantasan jentik nyamuk merupakan pengetahuan perilaku yang paling rendah diketahui oleh responden. Perilaku tersebut cenderung berada pada kategori kurang baik. Dari total responden, sebanyak 33 persen responden saja yang menjawab bahwa sampah harus ditempatkan sesuai dengan tempatnya dalam pewadahan sampah. Dari pertanyaan ini mayoritas responden menjawab sampah lebih baik dibakar. Selain itu, hanya sebanyak 63 persen responden tidak mengetahui cara yang dilakukan dalam pemberantasan nyamuk melalui 3M (Menutup, Menguras, dan Mengubur). Berkaitan dengan hal tersebut, kedua indikator tersebut turut berkaitan dari hasil FGD pertama yang diselenggarakan peneliti dengan topik permasalahan kesehatan dan lingkungan yang terjadi di wilayah Kelurahan Ciketing Udik khususnya RW 5. Adapun permasalahan yang dimunculkan oleh peserta FGD adalah sebagai berikut; (1) Minimnya kesadaran warga atas Posyandu, (2) Kapasitas pengetahuan kader dan pendanaan, (3) Akses air bersih, (4) Polusi udara, (5) Pendataan warga pendatang/ pemulung, (6) Lingkungan yang kumuh, (7) Masih adanya BABS (Buang Air Besar Sembarangan).

Dari ketujuh permasalahan yang kemudian dihadapi dan dirasakan oleh komunitas RW 5, lingkungan yang kumuh merupakan permasalahan yang paling banyak disoroti oleh partisipan. Hala ini dikarenakan masih 
banyaknya warga yang membuang sampah sembarangan dan juga melakukan pembakaran sampah. Partisipan menggambarkan bahwa lingkungan di area pemukimannya cukup kumuh. Terlepas dengan adanya TPST Bantargebang, yang membuat hiruk pikuk jalanan pemukiman tampak adanya sampah berceceran. Dengan adanya rumah-rumah kumuh dari pemulung dan atau pengepul yang menaruh sampahnya di depan pengepul hingga terlihat, namun juga perilaku baik warga lokal ataupun pendatang yang masih membuang sampah sembarangan dan juga membakar sampah di pekarangan.

Secara umum dari hasil survei yang dilakukan rata-rata pengetahuan responden akan persampahan mayoritas berada pada kategori cukup yakni sebanyak 60 persen. Responden yang memiliki pengetahuan persampahan dengan kategori baik sebanyak 30 persen dari jumlah responden, dan 10 persen memiliki pengetahuan persampahan yang sangat baik. Secara rinci pengetahuan persampahan responden yakni sebagai berikut.

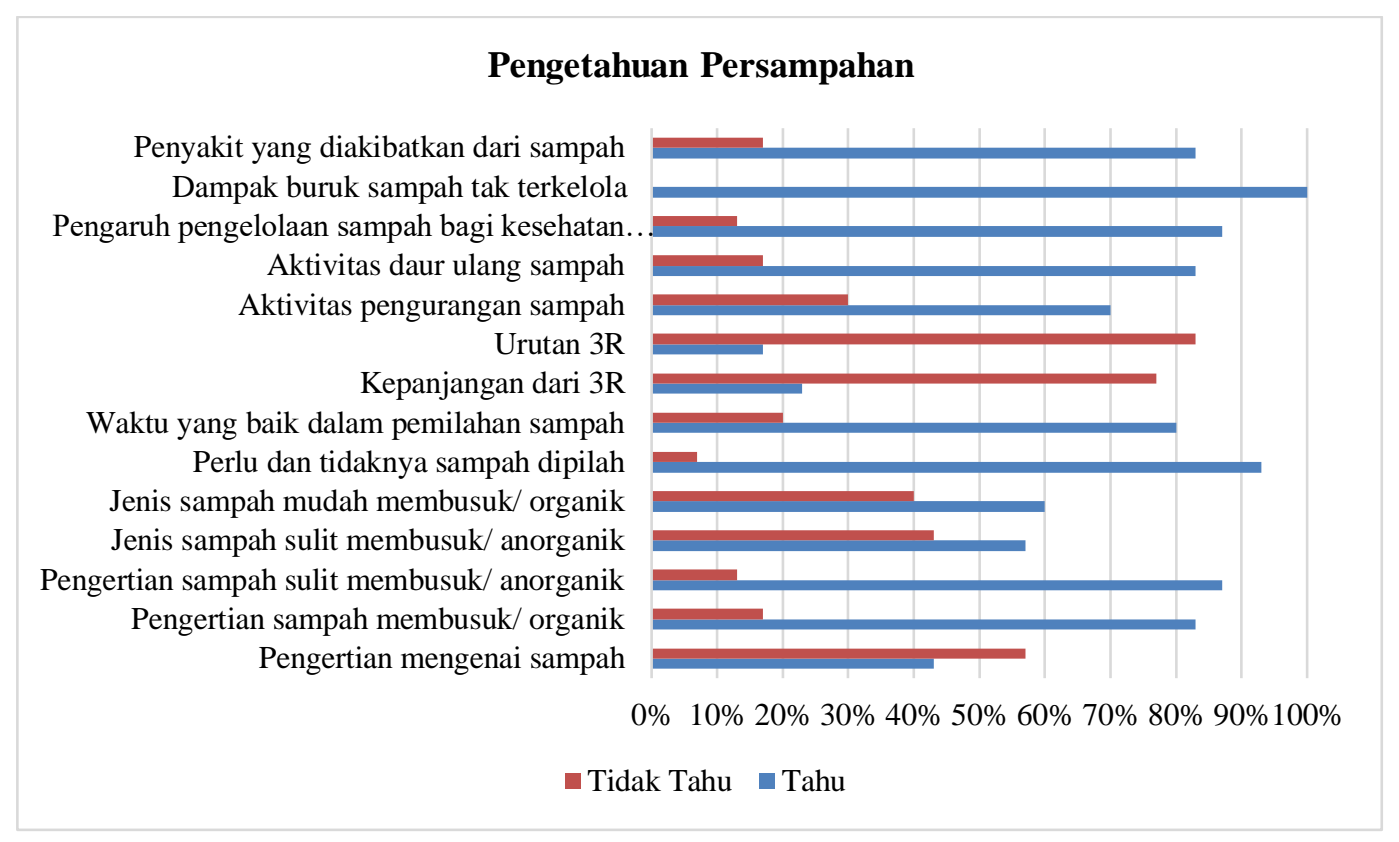

Gambar 3. Pengetahuan Persampahan

Dapat dilihat berdasarkan Gambar 3 di atas bahwa pengetahuan mengenai sampah yang dijawab oleh responden masih belum sepenuhnya memahami, rata-rata para responden masih memahami bahwa sampah adalah suatu benda yang menjijikkan. Selain itu responden masih belum mengetahui apa itu 3R (reduce, reuse, recycle) baik itu kepanjangan dari $3 \mathrm{R}$ itu sendiri yakni sebanyak 77 persen tidak mengetahui serta tidak memahami urutan penting dari $3 \mathrm{R}$ sebagai hierarki atas perlakuan sampah. Kecenderungan tersebut dapat disebabkan karena belum adanya ajang berbagi pengetahuan atas persampahan yang diselenggarakan di komunitas RW 5.

Wilayah komunitas RW 5 meskipun belum adanya penyelenggaraan akan ajang berbagi perihal pengetahuan persampahan, akan tetapi apabila dilihat dari jawaban responden mengenai pertanyaan yang berkaitan dengan pengertian sampah mudah dan sulit membusuk mayoritas responden mengetahuinya dengan baik yakni sebesar 83 persen dan 87 persen atau sebanyak 25 dan 26 responden dalam menjawab benar akan pertanyaan tersebut. Berkaitan dengan pengertian mengenai jenis sampah itu sendiri, mayoritas responden tidak semuanya dapat membedakan jenis sampah mudah dan sulit membusuk dengan baik. Akan tetapi, sebesar 93 persen responden mengetahui sampah baiknya harus dipilah terlebih dahulu sebelum dilakukan proses kelanjutannya.

Lingkungan turut memberi pengaruh terhadap pengetahuan komunitas dalam menilai sesuatu khususnya mengenai pemilahan sampah itu sendiri. Komunitas RW 5 yang dikelilingi oleh pemukiman pemulung dan pengepul, di mana pengepul dapat menerima sampah-sampah yang bisa didaur ulang saja untuk kemudian dibeli dari warga sekitar. Sebagaimana berdasarkan Rosyadi (2014) mengenai pengetahuan lokal bahwasanya suatu kekhasan pengetahuan dapat dimiliki oleh suatu masyarakat atau budaya tertentu sebagai hasil dari proses hubungan timbal-balik yang terjadi antara masyarakat dengan lingkungannya yang telah berkembang lama. Pada konteks komunitas RW 5, pengetahuan akan pemilahan sampah ini dapat dikatakan sebagai pengetahuan lokal yang didapatkan komunitas secara terus menerus dalam kesehariannya berinteraksi dengan pelaku daur ulang di sekitar TPST Bantargebang. Lebih lanjut, pada dasarnya responden memahami akan 
dampak dari pengelolaan sampah yang tidak baik yakni mengakibatkan banjir dan aroma yang tidak sedap, dan juga berdampak bagi kesehatan maupun bagi lingkungan. Sejalan dengan hal tersebut, meski tak semuanya responden menjawab dengan benar penyakit yang dapat ditimbulkan akibat sampah, namun sebanyak 83 persen atau setara 25 responden menjawab dengan benar penyakit-penyakit yang diakibatkan dari sampah.

\section{Kondisi Pengelolaan Sampah}

Dalam mengidentifikasi permasalahan sampah yang ada pada RW 5 Kelurahan Ciketing Udik Kecamatan Bantargebang Kota Bekasi, penelitian ini melakukan identifikasi yang didasari pada 5 (lima) aspek pengelolaan sampah. Adapun kelima aspek tersebut berdasarkan BSN (2008) antara lain; (1) Peraturan, (2) Kelembagaan, (3) Pendanaan, (4) Teknis Operasional, (5) Peran serta. Adapun kelima aspek tersebut saling terkait dan penting untuk diperhatikan pelaksanaannya dalam rangka mewujudkan sistem pengelolaan sampah yang efektif. Pada tingkat komunitas, peran serta dalam pengelolaan sampah merupakan salah satu bentuk partisipasi masyarakat yang sangat penting untuk secara sadar masyarakat dapat ikut andil dan terlibat dalam terciptanya kondisi lingkungan yang baik dan bersih dalam tatanan rumah tangga. Peran serta pada komunitas juga sangat berarti ketika seluruh wilayah dalam cakupan komunitas RW 5 dapat bersama-sama menerapkan pengelolaan sampah yang baik dan benar.

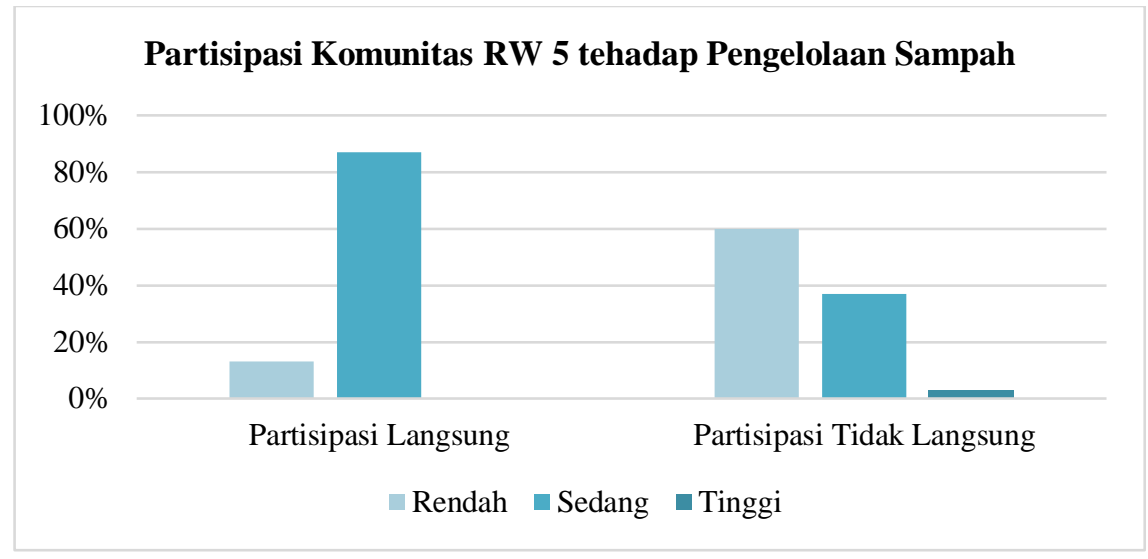

Gambar 4. Partisipasi Komunitas RW 5 terhadap Pengelolaan Sampah

Pada penelitian ini, peneliti turut menggambarkan partisipasi komunitas baik secara langsung maupun tidak langsung dalam pengelolaan sampah. Partisipasi langsung merupakan suatu tindakan dari peran serta masyarakat dalam melakukan aktivitas secara langsung secara fisik yang berhubungan dengan sampah. Menurut Nashori (2015) partisipasi langsung dapat diartikan dalam bentuk peran serta masyarakat dalam memilah sampah, menerapkan 3R, dan turut serta dalam melakukan kerja bakti. Berdasarkan hasil survei yang telah dilakukan, mayoritas partisipasi langsung komunitas RW 5 Kelurahan Ciketing Udik berada pada kategori partisipasi sedang yakni sebanyak 87 persen dari total responden, dan sebanyak 13 persen berada pada kategori rendah dalam partisipasi langsung akan pengelolaan sampah.

Sebagian responden turut melakukan praktik pengurangan sampah seperti membawa tas belanja, serta wadah makanan atau minuman sendiri. Selain itu, sebagian responden juga telah melakukan pemilahan sampah. Responden terbiasa untuk memilah sampah dalam kesehariannya. Namun, sampah yang dipilah mayoritas masih terbatas pada beberapa material sampah tertentu yang bernilai jual saja seperti kemasan botol air mineral. Di satu sisi, meski telah terdapat inisiatif perilaku individu responden secara langsung mengelola sampahnya, dari hasil observasi partisipasi langsung warga RW 5 mengenai pengelolaan sampah cenderung rendah. Hal tersebut terlihat dari sampah yang berceceran di beberapa titik. Terdapat aktivitas kerja bakti yang dilakukan setiap satu bulan sekali yang diselenggarakan Kelurahan bersama dengan RW RT di seluruh Kelurahan Ciketing Udik. Akan tetapi berdasarkan hasil wawancara tidak sepenuhnya seluruh warga mengikuti kegiatan ini secara rutin, dan kerja bakti cenderung dilakukan oleh warga yang sama yang juga telah aktif di dalam komunitas.

Mayoritas responden memiliki partisipasi yang rendah akan partisipasi tidak langsung dalam pengelolaan sampah yakni sebanyak 60 persen. Partisipasi sedang berada pada 37 persen dari total responden, sedangkan sisanya sebanyak 3 persen memiliki partisipasi tinggi. Dari hasil tersebut, dapat dikatakan wajar apabila warga 
RW 5 Kelurahan Ciketing Udik mayoritas memiliki partisipasi rendah akan partisipasi tidak langsung dalam pengelolaan sampah. Hal ini dikarenakan belum adanya program pengelolaan sampah yang berjalan secara terencana oleh komunitas. Komunitas RW 5 jarang mendengar adanya pembahasan atau sosialisasi akan persampahan yang ada di komunitas RW 5. Informasi yang berkaitan dengan perilaku baik dan tidak baiknya dalam pengelolaan sampah belum pernah didapatkan komunitas secara merata misalnya saja larangan dalam membuang sampah sembarangan dan membakar sampah diterima secara merata. Lebih lanjut berkaitan dengan partisipasi tidak langsung berupa iuran warga akan pengelolaan sampah juga tidak ada dikarenakan belum adanya program dan layanan pengelolaan sampah seperti layanan pengangkutan sampah.

Penyampaian aspirasi dan pemikiran warga merupakan salah satu aspek dari bentuk partisipasi masyarakat. Dalam hal penyampaian pendapat terhadap pengelolaan sampah, sebanyak 80 persen responden tidak pernah melakukan hal ini. Responden jarang menyampaikan kritik, keluhan atau pendapatnya akan pengelolaan sampah. Dari hal ini, komunitas RW 5 Kelurahan Ciketing Udik cenderung tidak acuh atas kondisi lingkungannya dan bahkan bisa saja tidak mengetahui mana yang baik dan tidak baik sehingga responden cenderung acuh dan mempengaruhi bentuk partisipasi responden akan pengelolaan sampah. Hal ini sesuai dengan Harun (2017) bahwa informasi dapat menjadi faktor yang bisa mempengaruhi pengetahuan dan perilaku seseorang sehingga semakin banyak seseorang memperoleh informasi, tentang pengelolaan sampah yang baik, maka pengetahuan akan baik dan dapat juga memiliki perilaku yang baik pula. Dari sini dapat dikaitkan bahwa penyuluhan turut menjadi peran penting khususnya dalam hal penguatan masyarakat yang berguna untuk memperluas akses akan informasi, layanan, dan inovasi (Amanah, 2007).

Berdasarkan paparan di atas, secara umum terkait partisipasi langsung dan tidak langsung cenderung berada pada kategori rendah. Apabila dikaitkan pada tipologi partisipasi masyarakat berdasarkan Arnstein (1969) komunitas RW 5 Kelurahan Ciketing Udik berada pada derajat penenteraman/ placation. Tipologi Placation sendiri diartikan bahwa ide program dan keputusan masih diinisiasi oleh pemerintah dan keterlibatan warga dalam program masih cenderung rendah. Komunitas dalam hal ini cenderung tergerak apabila program digerakkan oleh pihak eksternal baik itu pemerintah ataupun swasta. Sebagai contoh, aktivitas kerja bakti yang dilakukan setiap bulannya pada RW 5 merupakan program yang diinisiasi oleh Kelurahan Ciketing Udik. Pengelolaan kerja bakti masih lebih banyak didorong oleh kelurahan seperti halnya keputusan akan waktu penyelenggaraan kerja bakti dimasa pandemi yang dilakukan oleh pihak Kelurahan Ciketing Udik. Terkait dari pembiayaan operasional kerja bakti juga dibiayai oleh LPM Kelurahan Ciketing Udik.

Tidak adanya penyuluhan yang diberikan secara teratur, dan kurangnya keterlibatan dari sebagian kegiatan yang bersifat perencanaan dan pelaksanaan program dapat mengakibatkan masyarakat tidak mendapat informasi yang cukup sehingga masyarakat kurang termotivasi untuk melaksanakan kegiatan program secara keseluruhan (Tanjung et al., 2017). Dari penjelasan tersebut dapat disimpulkan bahwa partisipasi komunitas RW 5 cenderung rendah karena komunitas tidak dilibatkan secara langsung akan perencanaan hingga pengambilan keputusan dalam program-program yang dilakukan. Komunitas RW 5 tidak terbiasa dalam menginisiasi program terutama pada aspek lingkungan yang notabene tidak didapatkan informasi serta penyuluhan secara terencana dan teratur. Pada dasarnya, faktor dorongan dari tokoh masyarakat lokal sangat berpengaruh terhadap partisipasi komunitas akan pengelolaan sampah. Apabila semakin seringnya arahan yang diberikan dari tokoh masyarakat terkait kebersihan lingkungan, maka akan semakin besar kemungkinan komunitas dapat mengikuti himbauan yang diberikan (Waliki et al., 2020).

Terdapat tiga prasyarat akan tumbuh kembangnya dalam partisipasi masyarakat dalam hal ini berupa kemauan, kemampuan, dan kesempatan (Ankesa et al., 2016). Dari sisi kemauan, warga komunitas RW 5 mayoritas memiliki keinginan akan pengelolaan sampah lebih baik. Hal ini ditunjukkan dari survei yang dilakukan bahwasanya terdapat 83 persen menginginkan adanya pengelolaan sampah dan bersedia untuk memberikan iuran akan pengelolaan sampah. Pada dasarnya responden juga memahami pihak yang bertanggung jawab dalam pengelolaan sampah komunitas diawali oleh diri sendiri yakni sebanyak 73 persen responden yang menyatakan hal tersebut.

Di satu sisi terkait kesempatan, pada dasarnya warga komunitas secara luas memiliki kesempatan akan perilaku pengelolaan sampah yang dilakukan secara individu atas inisiatif dalam skala rumah tangga. Namun pada realitanya, kesempatan berupa akses pengetahuan dan juga akses untuk turut terlibat dalam perencanaan masih minim. Berdasarkan wawancara yang dilakukan oleh Dinas Lingkungan Hidup Kota Bekasi, peran UPTD Dinas Lingkungan hidup Kecamatan di Kota Bekasi sangat penting dalam menjangkau wilayah pada masingmasing kecamatan. Hanya saja peran UPTD Dinas Lingkungan Hidup tersebut cenderung lebih kepada ditargetkan dalam penambahan area layanan guna meningkatkan Pendapatan Asli Daerah. Dari hal ini disinyalir bahwa RW 5 sebagai salah satu permukiman kumuh di Kota Bekasi, belum masuk kepada sasaran

Jurnal Penyuluhan | Vol. 17 (02) 2020 | 281 
yang mendapatkan layanan tersebut. Sejalan dengan Cahyadi (2011) kebijakan pemerintah pada akhirnya menimbulkan terbatasnya akses dan tidak adanya pilihan yang diterima sebagian masyarakat dalam sistem pengelolaan sampah maupun sistem penyediaan perumahan kota.

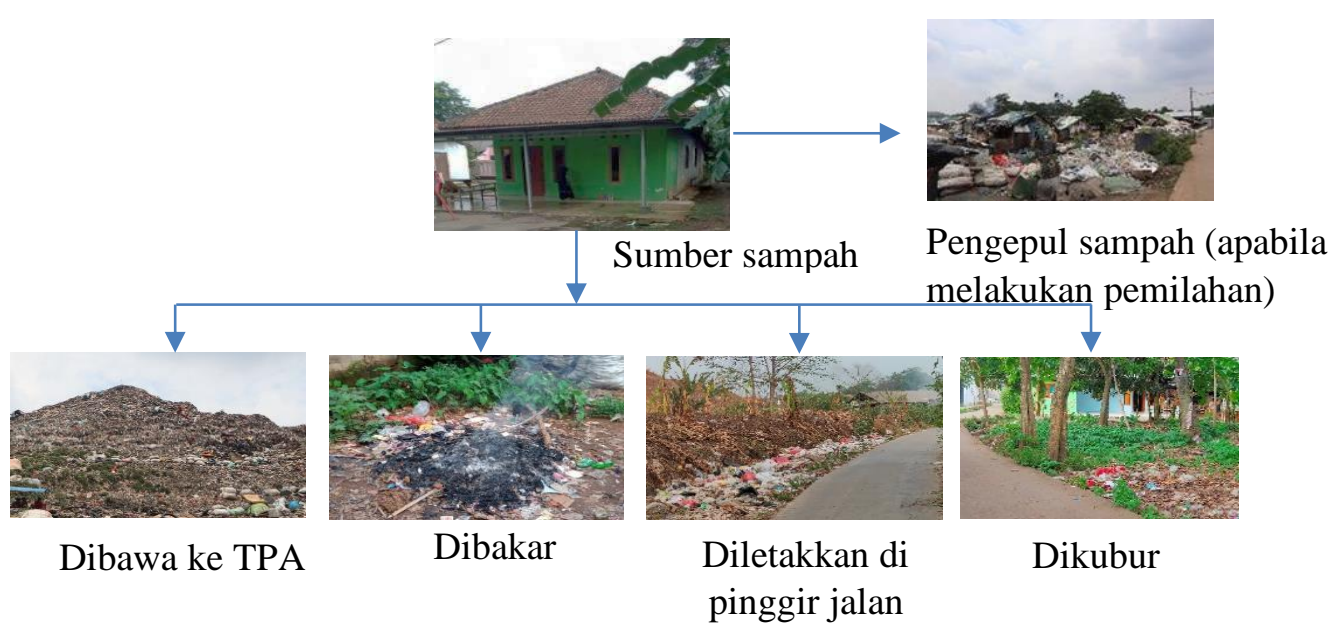

Gambar 5. Penanganan Sampah RW 5

Pengelolaan sampah di RW 5 belum berjalan baik. Komunitas RW 5 tidak memiliki sistem pengelolaan sampah sebagaimana tertuang pada SNI 19-2545-2002 tentang Tata Cara Teknik Operasional Pengelolaan Sampah Perkotaan (2002) terkait teknis operasional pengelolaan sampah yakni kurangnya pemilahan sampah di sumber, tidak adanya pengumpulan dan pengangkutan sampah sampai pembuangan akhir membuat RW 5 sebagai komunitas yang tidak mengelola sampahnya dengan baik. Sebagai gambaran berikut adalah bentuk penanganan sampah yang ada di RW 5.

Mayoritas komunitas RW 5 melakukan pembakaran sampah dalam penanganan sampahnya sehari-hari. Berdasarkan hasil FGD, salah satu alasan pembakaran sampah dilatar belakangi oleh masih tersedianya lahan yang dimiliki oleh penduduk asli sehingga tidak adanya urgensi untuk mengelola sampahnya lebih baik. Di satu sisi penduduk pendatang yang biasa meninggali rumah petak atau kontrakan yang lebih kecil cenderung membawa sampahnya langsung ke TPA ataupun diletakkan di pinggir jalan. Pada realitanya, khususnya di RW 5 belum ada pewadahan tempat sampah yang dilakukan oleh instansi atau komunitas terkait secara bersama-sama. Masing-masing warga mengadakan wadah sampahnya sendiri. Hal ini sesuai dengan penelitian Umaroh et al., (2016) bahwasanya rendahnya ketersediaan tempat sampah dan tersedianya lahan kosong yang masih luas menjadi pemicu warga setempat untuk dapat melakukan pembakaran sampah dan pembuangan ke sungai.

Sementara itu, berdasarkan hasil survei, sebanyak 73 persen dari total responden melakukan pembakaran sampah. Selain itu, dibuang di pinggir jalan 3 persen, dikubur 10 persen dan dibuang langsung ke TPA 13 persen. Di satu sisi, komunitas RW 5 Kelurahan Ciketing Udik sangat mengetahui benar aktivitas terkait pemilahan sampah, hal tersebut salah satunya dilatarbelakangi oleh lingkungan sekitar di mana banyak bandar pengepul dan pemulung yang melakukan pengambilan dan pemilahan sampah. Sebanyak 77 persen dari total responden melakukan pemilahan sampah meskipun sampah yang dipilah baru sebatas sampah yang bernilai jual saja seperti botol air mineral. Sejalan dengan Cahyadi (2011) bahwa pengelolaan sampah yang terdapat di pemukiman kumuh dapat dikategorikan menjadi dua, yaitu membuat sendiri tempat penampungan sampah (TPS) dan membuang langsung ke sungai atau tanah kosong. Minimnya akses dan perhatian menjadikan RW 5 yang notabene masih termasuk ke dalam permukiman kumuh tersebut tidak bisa dan ataupun belum bisa untuk menjadikan lingkungan lebih baik.

Dibutuhkan adanya perubahan perilaku yang kemudian dapat diharapkan untuk dapat mengurangi dampak dan permasalahan yang terjadi pada RW 5 untuk kemudian menjadi salah satu hal penting untuk dapat menjadi strategi perbaikan lingkungan dan kebersihan sekitar. Pada dasarnya perubahan perilaku dapat didorong dengan adanya kehadiran suatu bentuk program di masyarakat, dengan seperti itu setidaknya masyarakat dapat melakukan penerapan 3R dalam hal ini berupa pemilahan sampah, dengan itu terdapat pengaruh terhadap kondisi kebersihan lingkungan sekitar (Sidauruk, 2018). Sebagaimana menurut Weda et al., (2020), keputusan individu sebagai faktor internal menjadi sesuatu yang penting dalam proses perubahan, karena pada dasarnya 
secara pribadi setiap individu bisa menentukan keinginannya sendiri untuk mengikuti proses perubahan atau justru tetap melakukan kebiasaan lama.

Lebih lanjut, dari hasil identifikasi penerapan aspek peraturan terkait pengelolaan sampah yang ada di RW 5 Kelurahan Ciketing Udik. Kondisinya adalah absennya peraturan yang dimiliki pada tingkat lokal RW 5 dan RT serta Kelurahan Ciketing Udik sehingga hal ini juga dapat mempengaruhi tidak adanya sistem pengelolaan sampah yang berjalan di RW 5. Dalam menggambarkan hal tersebut, peraturan mengenai pengelolaan sampah yang berlaku pada Kota Bekasi apabila mengacu Peraturan Daerah Kota Bekasi No. 09 tentang Perubahan atas Peraturan Daerah Nomor 15 Tahun 2011 tentang Pengelolaan Sampah (2017). Terdapat kewajiban yang tertuang wajib dijalankan baik oleh pemerintah daerah maupun masyarakat. Secara ringkas kondisi kewajiban pemerintah daerah yang diatur adalah sebagai berikut; (1) Tidak ada fasilitas pemilahan yang disediakan oleh pemerintah daerah kepada komunitas RW 5, (2) Tidak ada pelayanan pengelolaan sampah yang diterima komunitas RW 5 seperti; tidak ada penerapan kegiatan pengumpulan sampah dari pemerintah daerah dan TPS yang disediakan serta alat angkut kepada komunitas RW 5, (3) Belum ada aktivitas pembinaan terkait pengelolaan sampah dan penyuluhan yang terstruktur berkelanjutan kepada komunitas RW 5.

Dari kondisi di atas, dapat dilihat beberapa kebutuhan dasar akan pengelolaan sampah belum sepenuhnya berjalan dengan baik. Adapun berdasarkan peraturan daerah tersebut, masyarakat juga wajib melakukan kewajibannya. Kondisi yang berjalan pada komunitas RW 5 adalah sebagai berikut; (1) Komunitas sudah melakukan pengurangan dan pemilahan pada tingkat individu namun belum pada tingkat komunitas dan juga belum adanya kegiatan pengumpulan dan pengangkutan serta Partisipasi didorong melalui tokoh dan kepemimpinan lokal, (2) Tidak ada lembaga pengelola sampah pada tingkat RW, (3) Mendapatkan kompensasi dari dampak TPST Bantargebang namun tidak dari TPA Sumur Batu dan TPA Burangkeng, (4) Terlibat dalam forum komunikasi antara Kelurahan Ciketing Udik dan LPM Kelurahan Ciketing Udik dalam ajang kerja bakti

Mayoritas pasal yang mengatur persampahan pada peraturan daerah tidak sepenuhnya ada dan dijalankan pada RW 5. Faktanya belum adanya organisasi yang mengatur dan mengelola sampah yang ditimbulkan oleh komunitas RW 5 dan tidak adanya pendanaan yang dimiliki oleh RW 5 terkait pengelolaan sampah. Sementara itu, untuk menyelenggarakan sistem pengelolaan sampah yang baik, diperlukan sinergi banyak pihak tidak hanya komunitas setempat melainkan pemerintah daerah selaku penentu kebijaksanaan dalam pembuat peraturan daerah yang mewajibkan setiap kelurahan memiliki tempat sebagai pusat kegiatan daur ulang sehingga dapat memberdayakan masyarakat dalam mengelola sampahnya di lingkungan masing-masing Hardiatmi (2011). Untuk dapat menyelenggarakan sistem pengelolaan sampah yang baik bahkan tidak hanya membuat peraturan saja, fungsi penegakkan aturan serta pengawasan dan evaluasi juga perlu diupayakan agar peraturan tidak hanya dibuat melainkan dilaksanakan. Seperti halnya pada Kota Bekasi, peraturan tersebut tidak sepenuhnya dilaksanakan pada Kelurahan Ciketing Udik khususnya RW 5.

Kondisi pengelolaan sampah masih minim dilaksanakan, seperti halnya anatomi tubuh manusia apabila satu organ tidak berfungsi dengan baik, maka organ lain turut terkena dampaknya dan menghasilkan penyakit atau kekacauan sistem. Begitu juga dengan pengelolaan sampah apabila antara satu aspek dengan aspek lain tidak saling berhubungan dan tidak berfungsi salah satunya, maka sistem pengelolaan sampah tidak dapat terselenggara dengan maksimal. Hal inilah yang turut disinyalir merupakan salah satu dasar dari permasalahan lingkungan dan kesehatan yang turut dirasakan oleh komunitas RW 5 Kelurahan Ciketing Udik Kelurahan Bantargebang Kota Bekasi.

\section{Peran Pemangku Kepentingan dalam PHBS dan Pengelolaan Sampah}

Apabila merujuk pada peranan pemangku kepentingan PHBS dalam Kementerian Kesehatan RI (2011) pemangku kepentingan dalam mendorong penerapan PHBS diturunkan dari pusat yakni Kementerian Kesehatan sampai ke instansi pemerintah terbawah yakni Kelurahan dan ataupun Desa dengan bantuan lembaga pemerintah terkait dan juga kelompok penggerak di masyarakat. Dalam Marzuki et al., (2016) terciptanya perubahan perilaku masyarakat khususnya pada bidang kesehatan, dipengaruhi oleh dukungan kebijakan pemerintah daerah sangat berpengaruh terhadap penerapan PHBS di masyarakat. Secara ringkas berikut adalah kondisi lapangan yang ada di Kelurahan Ciketing Udik khususnya pada RW 5 pada tingkat pemerintah kelurahan adalah sebagai berikut; (1) Tidak ada aturan di dalam Kelurahan yang mengatur spesifik tentang PHBS, (2) Tidak ada alokasi dana operasional yang dialokasikan khusus untuk PHBS (3) Tidak ada pelaporan secara khusus yang dipersiapkan, (4) Bantuan dana diupayakan oleh LPM Kelurahan Ciketing Udik dan sarana yang digunakan tidak terlalu jelas, secara umum lebih kepada penggunaan bangunan untuk pertemuan-pertemuan. 
Dari sisi forum keluarga siaga tingkat kelurahan yang diatur dalam pedoman PHBS, implementasinya tidak ada forum yang dimaksudkan yang berjalan untuk dapat mendorong penerapan PHBS. Selanjutnya pada tingkat lembaga kemasyarakatan, dalam hal ini masuk ke dalam program Posyandu dan PKK telah berperan aktif dalam menumbuhkan semangat keswadayaan. Namun lembaga tersebut tidak melakukan penyusunan rencana pembinaan PHBS rumah tangga secara rinci akan semua indikator PHBS begitu juga dengan implementasinya sebagaimana yang diatur dalam pedoman PHBS.

Dari paparan di atas, dapat dikatakan bahwa PHBS masih belum optimal diterapkan pada Kelurahan Ciketing Udik khususnya RW 5. Baik itu dari sisi kebijakan akan pengelolaan sampah, maupun PHBS itu sendiri masih kurang terlaksana dan termonitor dengan baik. Rendahnya upaya pemerintah setempat dalam mengadvokasi serta bina suasana, turut menjadi salah satu faktor rendahnya pengetahuan dan kesadaran masyarakat dalam berperilaku sehat Sidauruk (2018).

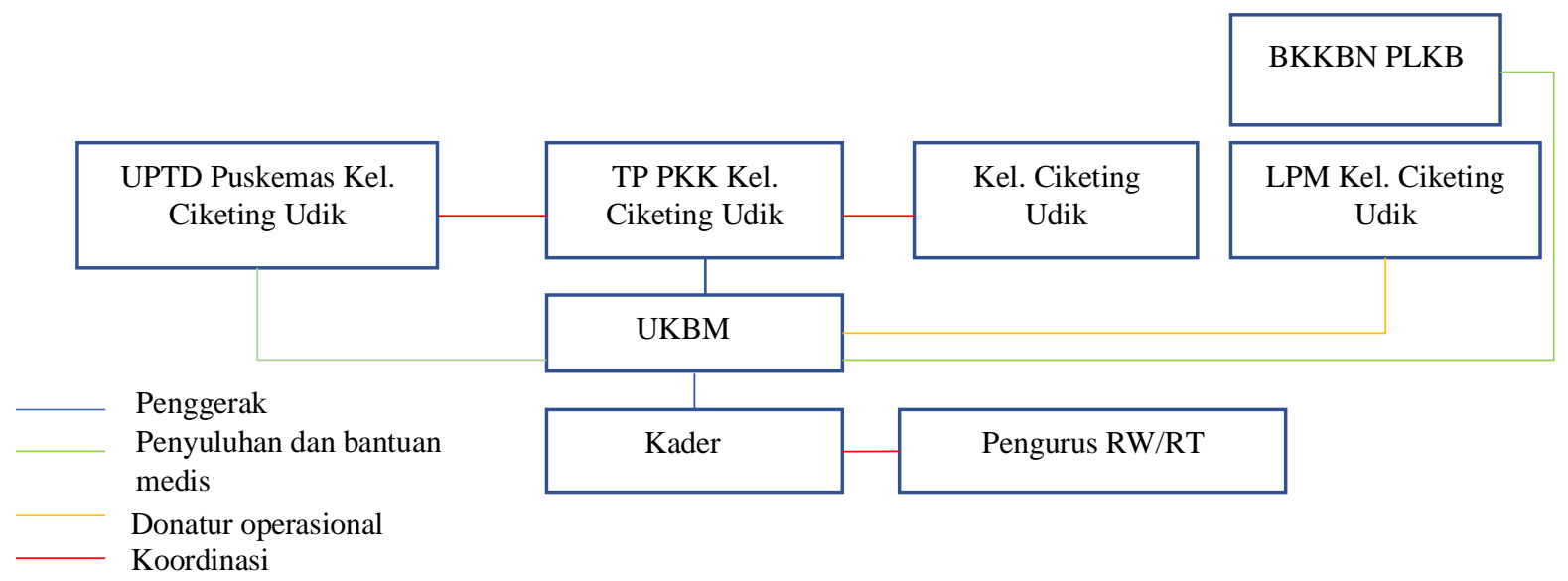

Gambar 6. Pemangku kepentingan dalam PHBS di RW 5

Berdasarkan Gambar 6 di atas terdapat beberapa peran antar lembaga yang terkait dan berperan dalam kualitas PHBS di RW 5 Kelurahan Ciketing Udik. Secara umum PHBS yang banyak bersinggungan langsung pada unit UKBM dalam hal ini melalui Posyandu. Posyandu menjadi sebuah lembaga sentral di mana unit ini menjadi titik temu hubungan antara masyarakat dan pemerintah atau lembaga setempat yang bertujuan untuk mewujudkan PHBS. Apabila di lihat dari gambar tersebut, UKBM Posyandu memiliki garis koordinasi inti antara PKK, Posyandu dan Kader sebagai penggerak dari aktivitas yang digawangi oleh komunitas setempat. RW 5 memiliki 2 Posyandu, dan setiap Posyandu RW 5 memiliki 10 orang kader yang bertugas pada operasional Posyandu bulanan serta aktivitas kebutuhan lainnya.

Pada aktivitas Posyandu sendiri, antara kader dengan Pengurus RW dan RT terlibat dalam garis koordinasi, di mana hubungan ini tidak berpengaruh langsung namun sebatas koordinasi saja, didukung adanya relasi antara pengurus RW dan RT yang cenderung memiliki istri yang kemudian menjadi seorang kader. Namun lebih lanjut, pada lingkup terkecil komunitas RW dan RT cenderung lebih banyak berperan dalam implementasi serta pelaksanaan kegiatan yang dilakukan di komunitas dibandingkan pemangku kepentingan lain pada garis merah. Hubungan PKK serta UPTD Puskemas Kelurahan Ciketing Udik dan Kelurahan Ciketing Udik cenderung bersifat koordinasi misalnya saja bersifat undangan akan aktivitas pembinaan, dan juga kebutuhan berbagi data yang berhubungan dengan aktivitas yang dilakukan pada secara keseluruhan.

Lebih lanjut Puskesmas sendiri bila dikaitkan dengan kader secara langsung, juga berperan untuk meningkatkan PHBS yang ada di wilayah Kelurahan Ciketing Udik terutama RW 5. Puskemas selaku bentuk dari kehadiran pemerintah melalui lembaga kesehatan mengisi bagian dengan adanya aktivitas penyuluhan mengenai PHBS baik pada tatanan rumah tangga baik kepada sasaran primer yakni masyarakat langsung pada ajang perkumpulan Posyandu atau sasaran sekunder melalui kader-kader yang dikumpulkan. Satu peran tambahan yang mengisi peningkatan kesadaran akan PHBS adalah peran PLKB (Penyuluh Lapangan Keluarga Berencana) yang secara ruang lingkup pekerjaan dalam hal ini menyasar kepada area-area perkumpulan untuk memberikan penyuluhan akan Keluarga Berencana tak terkecuali beberapa aspek yang menyangkut lingkungan dan kebersihan sekitar.

Apabila disimpulkan dari relasi antar pemangku kepentingan di atas, bentuk kehadiran pemerintah dalam hal ini lebih banyak terkait koordinasi saja tanpa adanya dukungan lebih lanjut semisal dari aktivitas peningkatan kapasitas ataupun penyediaan saranan dan prasarana yang cukup baik. Salah satu instansi pemerintah yang 
cenderung berperan sejauh ini cenderung berada pada Puskemas Kelurahan Ciketing Udik. Namun kembali lagi, PHBS belum terlalu menyentuh semua indikator untuk peningkatan PHBS secara komprehensif. Berdasarkan penelitian yang dilakukan oleh Mukaromah \& Rostyaningsih, (2016), salah satu inti kurangnya penyelenggaraan program PHBS dapat dilihat dari rendahnya pengetahuan serta kesadaran masyarakat dalam berperilaku sehat, sehingga masyarakat belum dapat meninggalkan kebiasaan buruk yang tidak sehat. Lebih lanjut pada praktiknya, pemerintah daerah kerap kali memiliki keterbatasan anggaran, sarana dan sumber daya, maka dari itu partisipasi masyarakat turut juga menjadi sebuah harapan terhadap suksesnya pengelolaan sampah rumah tangga Ismoyo et al., (2015).

\section{Analisis Kondisi Pengelolaan Sampah dan Peran Pemangku Kepentingan}

Permasalahan sampah yang dihadapi oleh RW 5 Kelurahan Ciketing Udik sebagaimana tertuang sebelumnya telah menjadi masalah sosial komunitas yang disadari dan diketahui bahwasanya butuh pemecahan dalam menanggulangi permasalahan yang terjadi. Apabila melihat dari kondisi pengelolaan sampah dari sisi aspek peraturan. Pemerintah melalui hal ini Kelurahan Ciketing Udik memiliki keterbatasan dalam menerapkan peraturan dikarenakan adanya keterbatasan anggaran. Pemerintah belum dapat memprioritaskan program pengelolaan sampah untuk dapat dimaksimalkan sepenuhnya pada setiap wilayah dalam cakupan Kelurahan Ciketing Udik.

Berdasarkan Dinas Lingkungan Hidup Kota Bekasi, Kelurahan Ciketing Udik sendiri juga belum menjadi sumber pendapatan asli daerah dikarenakan wilayahnya dapat dengan mudah membawa sampah langsung ke TPST Bantargebang dan bisa saja bukan menjadi sasaran yang dapat dimaksimalkan, selain itu keterbatasan dana untuk melakukan upaya-upaya pengurangan juga belum menjangkau banyak pihak. Sejalan dengan (Cahyadi 2011), faktor eksternal komunitas yang dominan justru menyebabkan sebagian masyarakat tidak punya pilihan dalam mengelola sampah dengan baik, beberapa dari kebijakan pemerintah yang ada pada akhirnya menyebabkan masyarakat tidak memiliki akses terhadap sistem pengelolaan sampah maupun sistem penyediaan perumahan kota.

Apabila melihat dari kondisi tersebut, pengelolaan sampah berbasis masyarakat perlu didorong oleh pemerintah daerah agar masyarakat tidak bergantung pada layanan pengumpulan dari pemerintah. Bentuk dorongan yang dapat dilakukan bisa beragam, seperti memfasilitasi pembangunan sarana fisik, mengadakan program pelatihan pengelolaan sampah, menyediakan lahan untuk pengelolaan sampah, atau membantu mengesahkan lembaga swadaya masyarakat untuk pengelolaan sampah agar dapat beroperasi dengan resmi dan tidak mendapat penolakan warga.

Mendapatkan dukungan pemerintah daerah seperti contoh-contoh di atas tentu akan mempermudah pengembangan pengelolaan sampah berbasis masyarakat. Namun, sering kali sebelum sebuah komunitas dapat mengajukan bantuan ke pemerintah daerah terkait pengelolaan sampah, komunitas tersebut perlu membuktikan bahwa mereka layak menerima dan memiliki kemampuan untuk mengelola bantuan tersebut dengan baik. Oleh karena itu, langkah pertama yang bisa dilakukan komunitas adalah mencoba mengelola sampah sebisa mungkin dengan modal yang mereka miliki saat ini sembari merencanakan pengelolaan sampah yang ideal bagi komunitas apabila mendapatkan bantuan dari pihak luar. Penelitian ini diharapkan dapat membantu masyarakat dalam memulai langkah pertama tersebut dengan melakukan pemetaan kondisi pengelolaan sampah yang mengacu pada kesiapan lima aspek manajemen pengelolaan sampah sesuai SNI 3242:2008, yaitu: aspek teknis operasional, peraturan, kelembagaan, peran serta masyarakat, dan pembiayaan.

Berangkat dari aspek teknis operasional pengelolaan sampah RW 5 Kelurahan Ciketing Udik yang mana mayoritas warga melakukan pembakaran sampahnya merasa penanganan sampah tersebut perlu jalan keluar untuk perbaikannya ke arah yang lebih baik. Untuk mewujudkan hal tersebut, langkah pertama yang dapat dilakukan adalah dengan menyediakan layanan pengumpulan sampah. Dalam melakukan pengumpulan sampah terdapat kebutuhan yang dibutuhkan seperti: (1) kendaraan pengangkut, (2) petugas kebersihan sampah, (3) pewadahan sampah di sumber, (4) kebutuhan operasional seperti bensin dan pemeliharaan serta honor petugas. Apabila merujuk pada aset komunitas dari sisi modal fisik, RW 5 sudah memiliki modal kendaraan pengangkutan berupa satu buah bak motor roda tiga, sedangkan dari sisi pewadahan di sumber, mayoritas warga memiliki caranya masing-masing dalam mewadahi sampah sebelum ditangani seperti memasukkan ke dalam kantong plastik, atau menyediakan pewadahan seperti ember.

Apabila komunitas berkeinginan untuk dapat lebih mengembangkan program pengelolaan sampah yang lebih tersistem dan terkelola secara baik dengan prinsip 3R (reduce, reuse, recycle) setidaknya terdapat dua contoh program pengelolaan sampah berbasis masyarakat yang telah diterapkan di berbagai wilayah di Indonesia 
yakni Bank Sampah dan TPS 3R. Bank Sampah merupakan salah satu strategi pengelolaan sampah pada tingkat masyarakat dengan rekayasa sosial untuk mengajak masyarakat memilah sampah dengan skema bank konvensional.

Berikutnya adalah TPS 3R sebuah program pengelolaan sampah berbasis masyarakat yang dipelopori oleh Kementerian PUPR. Sama seperti Bank Sampah, TPS 3R ini bertujuan mengurangi sampah dari sumber dengan menerapkan prinsip 3R. Dari sisi penyelenggaraannya TPS 3R memiliki pola pendekatan pengelolaan persampahan pada skala komunal atau kawasan, dengan melibatkan peran aktif pemerintah dan masyarakat, melalui pendekatan pemberdayaan masyarakat, termasuk untuk masyarakat berpenghasilan rendah dan/ atau yang tinggal di permukiman yang padat dan kumuh Kemenpupr (2018). Dari hal tersebut, secara umum TPS 3R lebih kepada sebuah jasa layanan pengelolaan sampah seperti jasa pengangkutan sampah yang dikelola oleh Kelompok Swadaya Masyarakat (KSM) setempat. Berbeda dengan Bank Sampah yang secara umum tidak melayani pengangkutan, namun lebih kepada menerima sampah-sampah yang bernilai saja.

Untuk menerapkan teknis operasional yang baik, diperlukan aturan-aturan dan sistem dalam menggerakkan program pengelolaan sampah agar sesuai dengan rencana. Dari sisi peraturan yang dapat diterapkan pada skala komunitas dengan pengelolaan sampah berbasis masyarakat, terdapat tiga minimum hal yang perlu ditetapkan yakni; (1) larangan penanganan sampah dengan pembakaran sampah, pembuangan di pinggir jalan, dan dikubur, (2) kesediaan warga dalam membayar iuran, (3) pengelola program pengelolaan sampah di komunitas RW 5.

Dalam mencapai kondisi minimum tersebut, RW 5 cukup memiliki tantangannya sendiri dalam menerapkan PHBS khususnya dalam pengelolaan sampah. Selain belum sepenuhnya memiliki saranan dan prasarana yang cukup baik terdapat minimnya pengetahuan dan perilaku pengelolaan sampah yang baik, hingga peraturan akan pengelolaan sampah yang belum maksimal menjadikan RW 5 masih dalam kondisi yang belum mumpuni untuk lebih baik dari sisi kebersihan lingkungannya. Hal menarik berdasarkan Wibowo (2009) bahwa perbedaan permukiman bersih dan kotor dalam hal ini kumuh adalah kesepakatan pemahaman yang dimiliki oleh komunitas setempat, karena pada dasarnya, pola perilaku kebersihan perlu dibangun, dibentuk, diorganisir secara berkelanjutan melalui tindakan-tindakan nyata dari individu penghuni kota.

Komunitas yang menjadi kunci untuk dapat mengubah kebiasaan dan sistem akan kesehatan dan lingkungannya atas inisiatifnya sendiri dalam menanggapi permasalahan yang dialami. Menjadi tantangan bersama bagi komunitas dan instansi terkait untuk menumbuhkan kesepakatan pemahaman dan konsensus bersama untuk dapat berubah. Keberlanjutan program pengelolaan sampah pada khususnya, peran tokoh perempuan dan tokoh formal seperti RT/ RW yang kemudian dapat sangat berperan Setyoadi (2018). Dalam hal ini, para penggerak seperti kader posyandu sebagai pihak yang bertugas pada tingkat komunitas secara sukarela dapat menjadi motor dalam promosi kesehatan dan lingkungan kemudian menjadi aktor penting dengan dukungan tokoh masyarakat serta RW dan RT di dalamnya. Peran tokoh masyarakat dalam kehidupan sehari-hari dapat menjadi faktor reinforcing dikarenakan tokoh masyarakat tersebut sudah berada di tengah lingkungan tempat tinggal masyarakat sehingga tokoh masyarakat dapat secara langsung memberikan contoh dan motivasi untuk berperilaku dalam cakupan PHBS (S \& Saputra, 2018).

\section{KESIMPULAN}

Pengetahuan komunitas RW 5 akan PHBS mayoritas berada pada kategori baik dan persampahan berada kategori cukup baik. Namun demikian, tidak sejalan dengan implementasi pengelolaan sampah yang terselenggara di dalamnya. Pada kondisi pengelolaan sampah saat ini, sampah belum terkelola dengan baik. Hal ini ditunjukkan dengan tidak adanya penerapan peraturan dari tingkat kelurahan sampai dengan tingkat komunitas RW 5, teknis operasional yang tidak tersistem dengan baik yang mengakibatkan mayoritas warga melakukan pembakaran sampahnya, dan juga tidak adanya kelembagaan/ organisasi dan pendanaan tersendiri akan pengelolaan sampah. Dari sisi partisipasi masyarakat baik secara langsung berada pada kategori sedang di mana dalam aktivitas harian komunitas sudah mulai dalam mengurangi sampah dan melakukan pemilahan sampah bernilai, akan tetapi dalam hal partisipasi tidak langsung cenderung masih rendah, di mana komunitas jarang memberikan pendapat dan kritik akan pengelolaan sampah dan juga membicarakannya dengan tetangga sekitar. Penerapan PHBS cukup baik pada sisi kesehatan ibu hamil, lansia dan balita, sedangkan dari sisi kebersihan lingkungan yakni pengelolaan sampah masih sangat minim. Hal ini sesuai dengan hasil penelitianpenelitian sebelumnya di mana program PHBS cenderung tidak berpengaruh signifikan terhadap pengetahuan dan praktik pengelolaan sampah di suatu komunitas. Minimnya akses informasi akan penerapan pengelolaan 
sampah skala komunitas serta pengawasan pemerintah akan hal ini menjadi tantangan tersendiri yang dihadapi komunitas RW 5 pada khususnya dan pemerintahan Kelurahan Ciketing Udik Kota Bekasi pada umumnya.

\section{DAFTAR PUSTAKA}

Amanah, S. (2007). Makna Penyuluhan dan Transformasi Perilaku Manusia. Jurnal Penyuluhan, 3(1). https://doi.org/10.25015/penyuluhan.v3i1.2152

Ankesa, H., Amanah, S., \& Asngari, P. S. (2016). Jurnal Penyuluhan, September 2016 Vol. 12 No. 2 Partisipasi Kelompok Perempuan Peduli Lingkungan dalam Penanganan Sampah di Sub DAS Cikapundung, Provinsi Jawa Barat. 12(2), 105-113.

Arnstein, S. R. (1969). A Ladder of Citizen Participation. Journal of the American Planning Association, 35: 4, 216-224.

Rencana Pembangunan Jangka Menengah Daerah Kota Bekasi 2018-2023, (2016).

BPS. (2014). Indikator Perilaku Peduli Lingkungan Hidup 2013 (S. D. S. L. Hidup (ed.); Vol. 2014). Badan Pusat Statistik. https://www.bps.go.id/publication/2013/12/27/26e979dbdd579d7b6db6941d/indikatorperilaku-peduli-lingkungan-hidup-2013.html

BPS. (2018). Statistik Lingkungan Hidup Indonesia (SLHI) 2018. In Badan Pusat Statistik/BPS-Statistics Indonesia. https://doi.org/3305001

SNI 19-2545-2002 tentang Tata Cara Teknik Operasional Pengelolaan Sampah Perkotaan, (2002). http://ciptakarya.pu.go.id/plp/upload/peraturan/SNI_19-24542002_Tata_Cara_Teknik_Operasional_ Pengelolaan_Sampah_Perkotaan.pdf

Cahyadi, R. (2011). Kaum Miskin Kota, Sampah, dan Rumah: Studi tentang Akses Migran Miskin terhadap Sumber Daya Lingkungan dan Perumahan di Tangerang. Masyarakat: Jurnal Sosiologi, 16(1), 77-91. https://doi.org/10.7454/mjs.v16i1.4875

Hardiatmi, S. (2011). Pendukung Keberhasilan Pengelolaan Sampah Kota. Jurnal Inovasi Pertanian, 1;1, 5066. https://doi.org/10.33061/innofarm.v10i1.630

Harun, H. (2017). Gambaran Pengetahuan dan Perilaku Masyarakat dalam Proses Pemilahan Sampah Rumah Tangga di Desa Hegarmanah. 6(2), 86-88. https://doi.org/10.24198/dharmakarya.v6i2.14789

Herdiansyah. (2018). Hubungan Unsur-Unsur Penyuluhan dengan Perubahan Perilaku Ramah Lingkungan pada Pengelolaan Sampah. IPB University.

Ismoyo, C., Muluk, M. R. K., \& Sales, C. (2015). Peningkatan Partisipasi Masyarakat dalam Pengelolaan Sampah Rumah Tangga. Reformasi: Jurnal Ilmiah Ilmu Sosial Dan Ilmu Politik, 5(1), 75-88.

Juliansah, M. H. (2010). Analisis Keberadaan Tempat Pengolahan Sampah Terpadu (TPST) Bantar Gebang Bekasi. Universitas Indonesia.

Kelurahan Ciketing Udik. (2018). Laporan Tahunan Kelurahan Ciketing Udik Tahun 2017.

Kemenpupr. (2018). Pedoman Teknis Pelaksanaan Kegiatan TPS 3R. Kementerian Pekerjaan Umum dan Perumahan Rakyat.

Kementerian Kesehatan RI. (2011). Pedoman Pembinaan Perilaku Hidup bersih dan Sehat (PHBS). In Peraturan Menteri Kesehatan No. 2406 TAHUN 2011 tentang Pedoman Umum Penggunaan Antibiotik. https://promkes.kemkes.go.id/pedoman-phbs

Listiawaty, R. (2020). Analisis Pelaksanaan Program Perilaku Hidup Bersih dan Sehat pada Tatanan Rumah Tangga di Wilayah Kerja Puskesmas X. Journal of Health Science and Physiotherapy, 134-142. https://doi.org/10.35893/jhsp.v2i2.46

Martinawati, M., Zahri, I., \& Faizal, M. (2016). Partisipasi Masyarakat dalam Pengelolaan Sampah Rumah Tangga: Sebuah Studi di Kecamatan Sukarami Kota Palembang. Jurnal Penelitian Sains, 18(1), 168182. https://doi.org/10.36706/jps.v18i1.35

Maryati, S. (2019). Penyediaan Infrastruktur dan Environmental Justice: Dampak Keberadaan Tempat Pembuangan Akhir Sampah bagi Masyarakat Sekitar. Planners InSight: Urban and Regional Planning Journal, 2(1), 35-42. https://doi.org/10.36870/insight.v2i1.28

Marzuki, A., Nurdin, \& Harisnal. (2016). Manajemen Penerapan Perilaku Hidup Bersih dan Sehat (PHBS) Tatanan Rumah Tangga di Kelurahan Kurao Pagang Padang. Journal Endurance, 1(October), 121-135. https://doi.org/10.22216/jen.v1i3.1015 
Maulana, C. Y., Romat, D., \& Ruhimat, M. (2014). Zonasi Tempat Pembuangan Sampah Terpadu (TPST) Bantargebang. Jurnal Pendidikan Geografi, 14; 2, 99-107. https://doi.org/10.17509/gea.v14i2.3400. g2392

Mukaromah, D. R. S., \& Rostyaningsih, D. (2016). Evaluasi Program Perilaku Hidup Bersih dan Sehat (PHBS) di Kelurahan Sarirejo Kecamatan Semarang Timur Kota Semarang. 2016, 5;2. https://doi.org/10.14710/ jppmr.v5i2.11326

Muljono, P. (2007). Learning Society, Penyuluhan dan Pembangunan Bangsa. 3(1). https://doi.org/10.25015/ penyuluhan.v3i1.2151

Nashori, A. M. Z. (2015). Pengetahuan, Sikap dan Partisipasi Masyarakat dalam Pengelolaan Sampah di Gili Trawangan Kabupaten Lombok Utara. IPB University.

Notoatmodjo, S. (2014). Ilmu Perilaku Kesehatan (2nd ed.). PT Rineka Cipta.

Peraturan Daerah Kota Bekasi No. 09 tentang Perubahan atas Peraturan Daerah Nomor 15 Tahun 2011 tentang Pengelolaan Sampah, 1 (2017).

Peraturan Presiden No 18 Tahun 2020 Tentang RPJMN 2020-2024, (2020). http://jdih.bappenas.go.id/ peraturan/detailperaturan/1037

Rosyadi, R. (2014). Sistem Pengetahuan Lokal Masyarakat Cidaun - Cianjur Selatan Sebagai Wujud Adaptasi Budaya. Patanjala : Jurnal Penelitian Sejarah Dan Budaya, 6(3), 431. https://doi.org/10.30959/ptj.v6i3. 173

S, P. W., \& Saputra, R. (2018). Faktor-Faktor Yang Berhubungan Dengan Perilaku Hidup Bersih Dan Sehat (PHBS) Di Desa Kualu Kecamatan Tambang Kampar. Photon: Jurnal Sain Dan Kesehatan, 8(2), 121128. https://doi.org/10.37859/jp.v8i2.725

Setyoadi, N. H. (2018). Faktor Pendorong Keberlanjutan Pengelolaan Sampah Rumah Tangga Berbasis Partisipasi Masyarakat di Kota Balikpapan dan Bogor. Jurnal Sains dan Teknologi Lingkungan, 10, 5166.

Sidauruk, V. S. (2018). Pengaruh Bank Sampah Terhadap Perilaku Pengelolaan Sampah, Pendapatan Keluarga Nasabah, dan Kebersihan Lingkungan (Studi Kasus: Bank Sampah Hijau Selaras Mandiri dan Bank Sampah Mawar Merah RW 12, Jakarta Pusat). IPB University.

Tanjung, N. S., Sadono, D., \& Wibowo, C. T. (2017). Tingkat Partisipasi Masyarakat dalam Pengelolaan Hutan Nagari di Sumatera Barat. Jurnal Penyuluhan, 13(1), 14. https://doi.org/10.25015/penyuluhan. v13i1.12990

Umaroh, A. K., Hanggara, H. Y., \& Choiri. (2016). Gambaran Perilaku Hidup Bersih Dan Sehat (PHBS) di Wilayah Kerja Puskesmas Bulu Kabupaten Sukoharjo Bulan Januari-Maret 2015. Jurnal Kesehatan, 9(1), 25. https://doi.org/10.23917/jurkes.v9i1.3375

UPST Dinas Lingkungan Hidup DKI Jakarta. (n.d.). UPST DLH DKI Jakarta. https://upst.dlh.jakarta.go.id/ tpst/data

Undang-Undang No. 1 Tahun 2011 Tentang Perumahan dan Kawasan Permukiman, UU Nomor 1 Tahun 2011 1 (2011). https://peraturan.bpk.go.id/Home/Details/39128

Waliki, Y., Tjolli, I., \& Warami, H. (2020). Perilaku Masyarakat dalam Mengelola Sampah Rumah Tangga di Distrik Manokwari Timur Kabupaten Manokwari. Cassowary, 3(2), 127-140. https://doi.org/10.30862/ casssowary.cs.v3.i2.59

Weda, W., Dewi, A., Tamitiadini, D., Yustisia, I. R., \& Brawijaya, U. (2020). Pendekatan Transtheoretical sebagai Model Adaptasi Perubahan Perilaku Sadar Lingkungan di Provinsi Bali. Profetik Jurnal Komunikasi, 13(1), 138-154. https://doi.org/10.14421/pjk.v13i1.1711

Wibowo, I. (2009). The Pattern of Cleanliness:A Study of Environmental Psychology of Urban Waste Management. Makara Human Behavior Studies in Asia, 13(1), 37. https://doi.org/10.7454/mssh. v13i1.207

Wijayanti, R. (2019). Identifikasi pola sebaran spasial permukiman kumuh dan arahan penanganannya di Kota Bekasi [tesis]. IPB University. 